\title{
Simultaneous quantification of human herpesvirus 8 DNA by real time PCR in different tissues of HIV infected cuban patients with Kaposi's sarcoma
}

\author{
Vivian Kourí ${ }^{1 *+}$, Pedro A Martínez ${ }^{1 \dagger}$, Orestes Blanco ${ }^{1}$, Virginia Capó ${ }^{1}$, María E Rodríguez', María del C Dovigny ${ }^{1}$

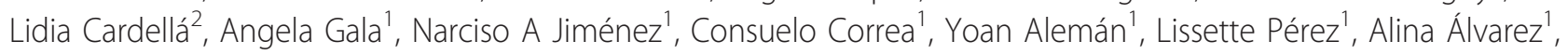 \\ Ulrich Hengge ${ }^{3}$
}

\begin{abstract}
In Cuba, previous reports have shown an increase of epidemic KS, reaching a total of 120 cases by the end of 2007, despite the use of HAART. To evaluate and compare the role of human herpes virus 8 (HHV-8) viral loads in different compartments of AIDS-related Kaposi's sarcoma (AIDS-KS) patients real-time polymerase chain reaction (RT-PCR) was used to determine the genome copy number of HHV-8 in plasma, saliva, tissue and peripheral blood mononuclear cells (PBMC) of 49 AIDS-KS patients. Overall, 98\% of AIDS-KS patients harbored detectable HHV-8. HHV-8 could be detected in $91.6 \%$ of KS tissue lesions showing the highest viral load (median log $=3.14$ copies/ 100 ng DNA) followed by saliva and PBMC which were positive in 78\%, and 69.2\%; respectively. In contrast, HHV-8 was detected in only $37 \%$ of plasma samples, which also showed lower viral loads. Men who had sex with men (MSM) were more likely to have three-times higher HHV-8 genome copies in KS lesions when compared with tissues from heterosexuals individuals (OR 3; $95 \% \mathrm{Cl} 1.1$ to 12.5). These results emphasize the systemic nature of HHV8-infection and demonstrate the possible role of saliva in HHV-8 transmission among MSM.
\end{abstract}

\section{Findings}

One hundred and forty-two clinical samples belonging to 49 patients with epidemic KS histologically diagnosed in the Pathology Department at the Institute of Tropical Medicine Pedro Kourí between 2004-2007 were included. The research was approved by local and national ethics committees; all subjects provided their written informed consent. Clinical, immunological and epidemiological data from each patient are depicted in Table 1.

Different types of samples (41 saliva, 48 tissues, 26 $\mathrm{PBMC}$, and 27 plasma) obtained from each individual were tested at the same time. PBMC and plasma were obtained by separation of $20 \mathrm{~mL}$ of citrated whole blood using a Ficoll separation gradient (SIGMA, UK). Paraffin was removed from tissues by xylene treatment according to published protocols [1]. DNA extraction was

\footnotetext{
* Correspondence: vkouri@ipk.sld.cu

† Contributed equally

'Institute of Tropical Medicine "Pedro Kouri", Havana City, Cuba

Full list of author information is available at the end of the article
}

performed using the QIAamp DNA Mini Kit (QIAGEN, Germany) and the genomic DNA (gDNA) concentration was determined using spectrophotometer (GeneQuant II, Pharmacia Biotech, EUA) and adjusted to $100 \mathrm{ng}$, with the exception of plasma where $10 \mathrm{uL}$ were directly used since it was not possible to quantify the gDNA. In order to obtain the standard DNA for absolute quantification, gDNA was extracted from the BCBL-1 cell line and the DNA copy numbers was determined by spectrophotometer as well. Then, the OD concentration was converted to DNA copy number following methods published elsewhere [2]. Once the gDNA copy number from BCBL-1 cell line was calculated, it was adjusted to 1 million copies and a standard curve with serial tenfold dilutions (from $10^{6}$ to 10 copies) assayed in triplicates was prepared. Once the run finished, the standard curve was automatically generated by the LightCycler software version 3.3, using the Second Derivative Maximum (SDMM) method. In additon, the detection of Human $\beta$ globin gene was used as internal control in
C Biomed Central

(c) 2010 Kourí et al; licensee BioMed Central Ltd. This is an Open Access article distributed under the terms of the Creative Commons Attribution License (http://creativecommons.org/licenses/by/2.0), which permits unrestricted use, distribution, and reproduction in any medium, provided the original work is properly cited. 
Table 1 Demographical, epidemiological and clinical characteristic of the study population

\begin{tabular}{|c|c|c|}
\hline Demographical, epidemiological and clinical variables & \multicolumn{2}{|c|}{ AIDS-KS N = 49} \\
\hline Mean Age & \multicolumn{2}{|c|}{38.2 years (Range: $22-57$ ) } \\
\hline \multirow[t]{2}{*}{ Gender } & Female & $2(4.1 \%)$ \\
\hline & Male & $47(95.9 \%)$ \\
\hline \multirow[t]{3}{*}{ Race } & White & $35(71.4 \%)$ \\
\hline & Mulatto & $9(18.4 \%)$ \\
\hline & Black & $5(10.2 \%)$ \\
\hline \multirow[t]{2}{*}{ Sexual orientation } & Heterosexual & $5(10.2 \%)$ \\
\hline & Homosexual & $44(89.8 \%)$ \\
\hline \multirow[t]{3}{*}{ Type of KS according to macroscopic classification } & Cutaneous & $35(71.4 \%)$ \\
\hline & Mucocutaneous & $7(14.3 \%)$ \\
\hline & Disseminated & $7(14.3 \%)$ \\
\hline \multirow[t]{4}{*}{ Histological classification } & Macular & $16(32.6 \%)$ \\
\hline & Patch & $7(14.3 \%)$ \\
\hline & Tumor & $14(28.6 \%)$ \\
\hline & Not classified & $12(24.5 \%)$ \\
\hline Mean HIV viral load* (copies/mL) & \multicolumn{2}{|c|}{65135 (Range: < 50-580 000) } \\
\hline Mean T CD4+ cell count $\left(\mathrm{cel} / \mathrm{mm}^{3}\right)$ & \multicolumn{2}{|c|}{295 (Range: 8-974) } \\
\hline \multirow[t]{3}{*}{ T CD4+ cell count } & $<200$ & $21(42.9 \%)$ \\
\hline & $200-499$ & $21(42.9 \%)$ \\
\hline & $>500$ & $7(14.2 \%)$ \\
\hline Mean number of years after KS diagnosis & \multicolumn{2}{|c|}{1.6 years } \\
\hline
\end{tabular}

*Data not available from 7 patients.

each clinical sample (with exception of plasma) for measuring of the exact amount of input DNA [3].

RT-PCR primers and conditions were described previously by Watzinger et al [4] with minor modifications adapted for the LightCycler 1.5 [4]. Samples were considered negative if the $\mathrm{Ct}$ value exceeded cycle 40, or if the copy number was below 10 copies. All patients or samples with more than 10 copies were considered positive, thus infected with HHV-8. For statistical analysis SPSS 11,5 (Inc. SPSS, Chicago, IL, the USA) and Statgraphic were used. Tests for comparison of proportions between the averages were performed using the Chisquare test and the Pearson coefficient of correlation for $95 \%$ confidentiality.

To our knowledge, this is the first report, where HHV-8 viral load has been simultaneously determined in four different fluids and cells (affected tissue, saliva, plasma and PBMC) from the same AIDS-KS patients. Forty-eight (98\%) of the 49 AIDS-KS patients had detectable levels of HHV-8 DNA at least in one of the samples studied, (67\% of patients had more than 2 samples positives), with the virus being more frequently detected in KS lesions (44 tissues, 91.6\%) followed by saliva in $78 \%$ and PBMC in $69.2 \%$. The detection probability and viral load being significantly lower in plasma (37\%). There was a positive correlation between the detection of HHV-8 in tissue and the detection in saliva or PBMC $(\mathrm{p}<0.01)$ that was not observed for plasma (Table 2). Although PCR inhibitions could be a possible explanation for the 4 negative results from KS lesions, several other factors that may have limited KSHV detection, like lesion sampling, since the lesion sample was not always the same for molecular detection and diagnosis. In addition, a possible histological inaccuracy could not be excluded because some patients were diagnosed as early stage of KS [5]. However, the percentage of KSHV DNA detected in the present study is similar to previous results published by Mendez and colleagues [6] and higher than the $87 \%$ of KSHV DNA detection reported by Kennedy and co-authors [7].

All fresh frozen tissues, PBMC and saliva samples, were confirmed to have the same amount of the input gDNA in100 ng, by detecting similar crossing point $(\mathrm{Cp})$ amplification signal of the Human $\beta$ globin gene among them (average Cp: 24.08, range: 22-25); in contrast, paraffinembedded tissues showed a gDNA amplification signal after cicle 29 (range:27-32), probably due to degradation [8]. This result was consistent with the detection of HHV-8 load significantly higher in fresh frozen tissue than in paraffin-embedded tissue $(\mathrm{p}<0.003)$ (Table 2).

Despite the difference detected between fresh frozen and paraffin-embedded tissue, when copy numbers from 
Table 2 KSHV load levels in different fluid and cells from each KS patient

\begin{tabular}{|c|c|c|c|c|}
\hline ID & Tissue copies/100 ng gDNA & PBMC copies/100 ng gDNA & Saliva copies/100 ng gDNA & Plasma copies/uL \\
\hline ADS-KS1 & 293 (fresh frozen tissue) & 41 & 71 & ndt \\
\hline ADS-KS2 & 28200 (fresh frozen tissue) & 32 & 193 & ndt \\
\hline ADS-KS3 & 17670 (fresh frozen tissue) & 22 & 134 & $\mathrm{ndt}$ \\
\hline ADS-KS4 & 51610 (fresh frozen tissue) & 130 & 62 & $\mathrm{ndt}$ \\
\hline ADS-KS5 & 294 (fresh frozen tissue) & ndt & 269 & 92 \\
\hline ADS-KS6 & 167 (paraffin embedded) & 40 & 130 & ndt \\
\hline ADS-KS7 & 15850 (fresh frozen tissue) & $\mathrm{ndt}$ & ndt & $\mathrm{ndt}$ \\
\hline ADS-KS8 & 30000 (fresh frozen tissue) & ndt & 145 & ndt \\
\hline ADS-KS9 & ndt (paraffin embedded) & ndt & $\mathrm{ndt}$ & ndt \\
\hline ADS-KS10 & 78 (paraffin embedded) & 119 & 121 & 239 \\
\hline ADS-KS11 & 1952 (fresh frozen tissue) & 38 & 191 & 39 \\
\hline ADS-KS12 & 21840 (fresh frozen tissue) & 390 & 96 & 49 \\
\hline ADS-KS13 & 529 (paraffin embedded) & $\mathrm{ndt}$ & $\mathrm{ndt}$ & 2452 \\
\hline ADS-KS14 & 37630 (fresh frozen tissue) & $\mathrm{ndt}$ & 394 & ndt \\
\hline ADS-KS15 & 26090 (fresh frozen tissue) & 19 & $\mathrm{ndt}$ & ndt \\
\hline ADS-KS16 & 57 (paraffin embedded) & ndt & 77 & $\mathrm{ndt}$ \\
\hline ADS-KS17 & 23 (paraffin embedded) & ndt & 49 & 68 \\
\hline ADS-KS18 & 477 (paraffin embedded) & 307 & 23 & 30 \\
\hline ADS-KS19 & 42 (paraffin embedded) & 31 & 160 & ndt \\
\hline ADS-KS20 & 1725 (fresh frozen tissue) & $\mathrm{ndt}$ & 145 & $\mathrm{ndt}$ \\
\hline ADS-KS21 & ndt (fresh frozen tissue) & 42 & 2482 & ndt \\
\hline ADS-KS22 & 0 (fresh frozen tissue) & 40 & 584 & ndt \\
\hline ADS-KS23 & 22 (paraffin embedded) & 26 & 343 & 20 \\
\hline ADS-KS24 & 1418000 (fresh frozen tissue) & 19 & 236 & 65 \\
\hline ADS-KS25 & 36460 (fresh frozen tissue) & 167 & 32 & 55 \\
\hline ADS-KS26 & 749 (fresh frozen tissue) & NS & 172 & NS \\
\hline ADS-KS27 & 47050 (fresh frozen tissue) & NS & NS & NS \\
\hline ADS-KS28 & 58 (fresh frozen tissue) & NS & $\mathrm{ndt}$ & NS \\
\hline ADS-KS29 & 389 (fresh frozen tissue) & NS & $n d t$ & NS \\
\hline ADS-KS30 & 39830 (fresh frozen tissue) & NS & 89 & NS \\
\hline ADS-KS31 & 10040 (paraffin embedded) & NS & NS & NS \\
\hline ADS-KS32 & 819 (fresh frozen tissue) & NS & NS & NS \\
\hline ADS-KS33 & 128800 (fresh frozen tissue) & NS & 445 & NS \\
\hline ADS-KS34 & ndt (fresh frozen tissue) & NS & 366 & NS \\
\hline ADS-KS35 & 206 (fresh frozen tissue) & NS & $\mathrm{ndt}$ & NS \\
\hline ADS-KS36 & 68280 & NS & 114 & ndt \\
\hline ADS-KS37 & 877 (paraffin embedded) & NS & NS & NS \\
\hline ADS-KS38 & 30730 (fresh frozen tissue) & NS & 131 & NS \\
\hline ADS-KS39 & NS & 53 & 9447 & $\mathrm{ndt}$ \\
\hline ADS-KS40 & 867 (paraffin embedded) & NS & $\mathrm{ndt}$ & NS \\
\hline ADS-KS41 & 30520 (fresh frozen tissue) & NS & 148 & NS \\
\hline ADS-KS42 & 35 (fresh frozen tissue) & NS & NT & NS \\
\hline ADS-KS43 & 31740 (fresh frozen tissue) & NS & 177 & NS \\
\hline ADS-KS44 & 10120 (fresh frozen tissue) & NS & 132 & NS \\
\hline ADS-KS45 & 139800 (fresh frozen tissue) & NS & NS & NS \\
\hline ADS-KS46 & 2483 (fresh frozen tissue) & NS & $\mathrm{ndt}$ & NS \\
\hline ADS-KS47 & 163 (fresh frozen tissue) & NS & NS & NS \\
\hline
\end{tabular}


Table 2 KSHV load levels in different fluid and cells from each KS patient (Continued)

\begin{tabular}{cccccl}
\hline ADS-KS48 & 28680 (fresh frozen tissue) & NS & 230 & NS \\
\hline ADS-KS49 & 58 (paraffin embedded) & NS & NS & NS \\
\hline
\end{tabular}

Abbreviations: Ndt: non detectable; NS: no sample available.

different samples (tissue-plasma, tissue-saliva, tissuePBMC, plasma-saliva, PMBC-saliva, and PBMC-plasma) within a given individual were compared, a significantly higher HHV-8 viral load in KS lesions compared to all the other samples $(\mathrm{p}<0.05)$ was detected (Figure 1$)$. One of the reasons that may explain why the higher $\mathrm{HHV}-8$ load is detected in tissue, specifically in the case of HIV infection, is that the HIV tat protein promotes the replication of $\mathrm{HHV}$-8-stimulated cell proliferation and inhibits apoptosis of spindle cells infected with HHV-8 [9,10]. Recent reports have described a higher HHV-8 load of AIDS-KS lesions compared with endemic KS, although the differences were not statistically significant.
HHV-8 load in saliva and PBMC was significantly lower than in tissue $(\mathrm{p}<0.05)$ and significantly higher than in plasma ( $\mathrm{p}<0.05$; Figure 1 ), however there were no statistic differences between the viral load in saliva and PBMC ( $\mathrm{p}>0.05$ ). Of note, saliva represented the second most frequent source for HHV-8 detection (Figure 1). In the light of previous reports [11-13] and consistent with the present results transmission by saliva may contribute to the spread of $\mathrm{HHV}-8$ infection among the HIV seropositive population besides sexual intercourse [14]. It still remains controversial why, if saliva is the main source of virus, HHV-8 infection shows a sexual pattern of transmission. Nevertheless, saliva is the only mucosal fluid in which infectious HHV-8 has been

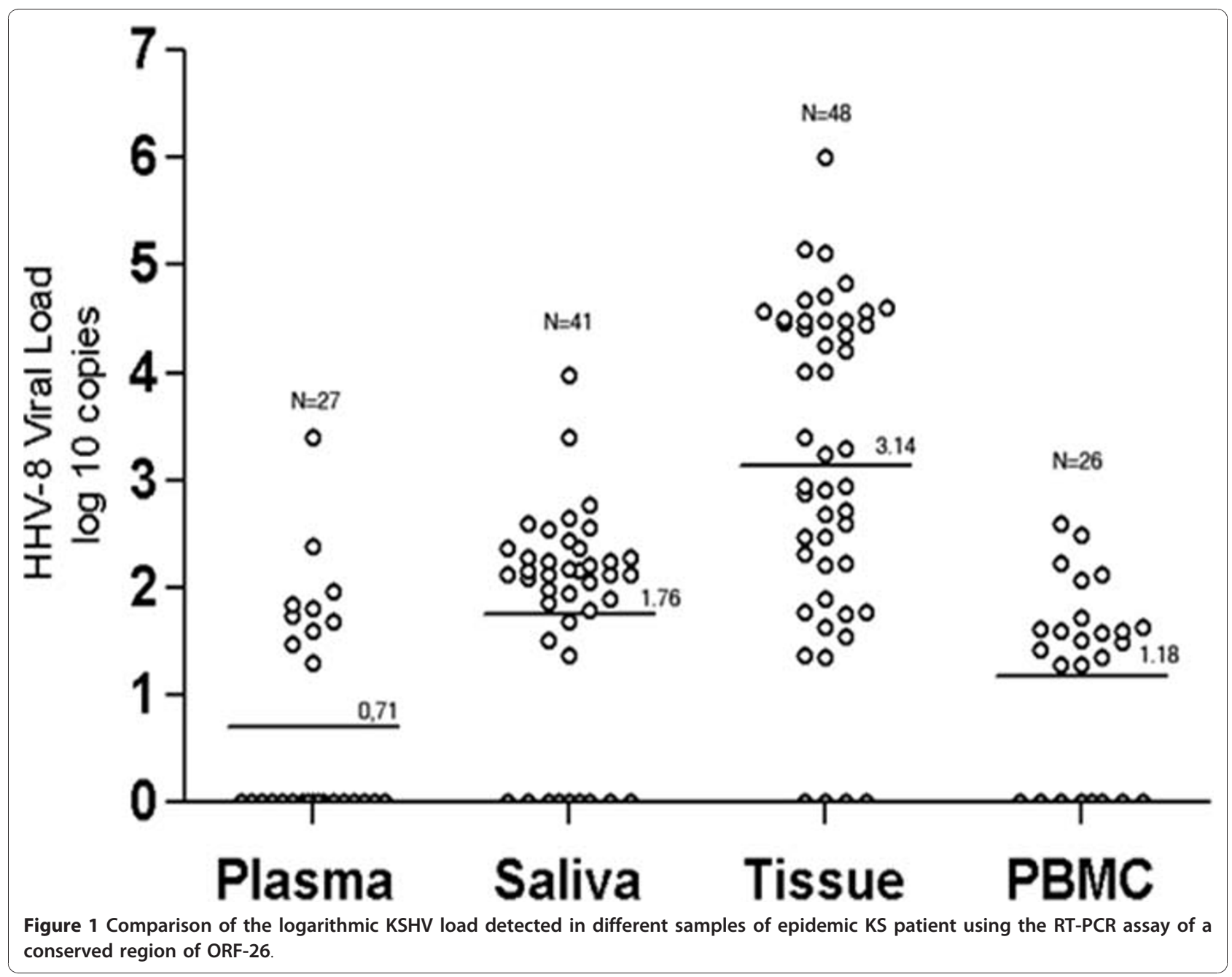


identified, although factors associated with HHV-8 salivary shedding remain unclear [15]. Moreover, future research will need to assess the possible impact of saliva in HHV-8 transmission among Cuban HIV seronegative individuals.

Most authors agree that the viral genome present in PBMC of AIDS-KS patients occurs in a latent state, but the role of $\mathrm{HHV}-8$ persistence in $\mathrm{PBMC}$ with regard to the pathogenesis of KS remains unclear [16]. The lower copy number of HHV-8 detected in PBMC in comparison to $\mathrm{KS}$ tissue, could be due to its latent state within this compartment, in contrast to viral expression present in lesional spindle cells [17].

Harrington and colleagues demonstrated that the presence of HHV-8 in plasma is intermittent [18]. For other viral infections, plasma viral load has been used as the best marker to estimate disease progression [19-21]. However, this does not seem to be true for $\mathrm{KS}$ and HHV-8, as has been proposed by Polstra and colleagues [22]. Hundred percent of Cuban AIDS-KS patients, in whom HHV-8 was detected in plasma also tested positive in other clinical samples (saliva, KS tissue, PBMC). Thus, viremia could occur in those patients with active viral replication, alternating with latency periods where the virus is not detected in plasma, as has been reported for other members of the Herpesviridae family [23].

There was a significant Pearson's correlation when each patient's tissue $\mathrm{HHV}-8$ levels were compared with saliva and PBMC ( $<<0.01)$; however, this correlation did not exist for plasma samples (Figure 2). We did not find association between the HHV-8 viral load in all the samples analyzed with: CD4 cell counts, HIV viral load, type of KS (cutaneous, mucocutaneous and systemic), the histological stage (macular, patch and tumoral) nor the number of years elapsed between the KS diagnosis and death $(\mathrm{p}>0.05)$.

In our study, Caucasian AIDS-KS patients were more likely to be positive for HHV-8 infection than black or mulatto KS patients $(\mathrm{p}=0.006)$. There is no previous report regarding the association of $\mathrm{HHV}-8$ levels with skin color. However, it has been described several times that AIDS-KS is more frequent in individuals with white skin [24]. Some authors have proposed a genetic predisposition to $\mathrm{HHV}-8$ infection in individuals with certain HLA types ( $A^{*} 6801$ and DRB1*04) that tend to have increased viral excretion in saliva e.g. in African women [25]. MSM were more likely to have three-times higher HHV-8 genome copies in KS lesions when compared with tissues from heterosexuals individuals (OR 3; 95\% CI 1.1 to 12.5$)$. This seems to be a very important finding that confirms what has been reported by other authors regarding sexual risk behaviors that are more prevalent in homosexual intercourse [26]. With the present study we confirm that $\mathrm{HHV}-8$ produces a systemic infection in different body compartments and that the highest HHV-8 levels were produced in lesional KS tissue. Furthermore, saliva has been recognized as an important reservoir for $\mathrm{HHV}-8$ transmission.

One of the main challenges for researchers is to identify the exact mode of virus transmission following

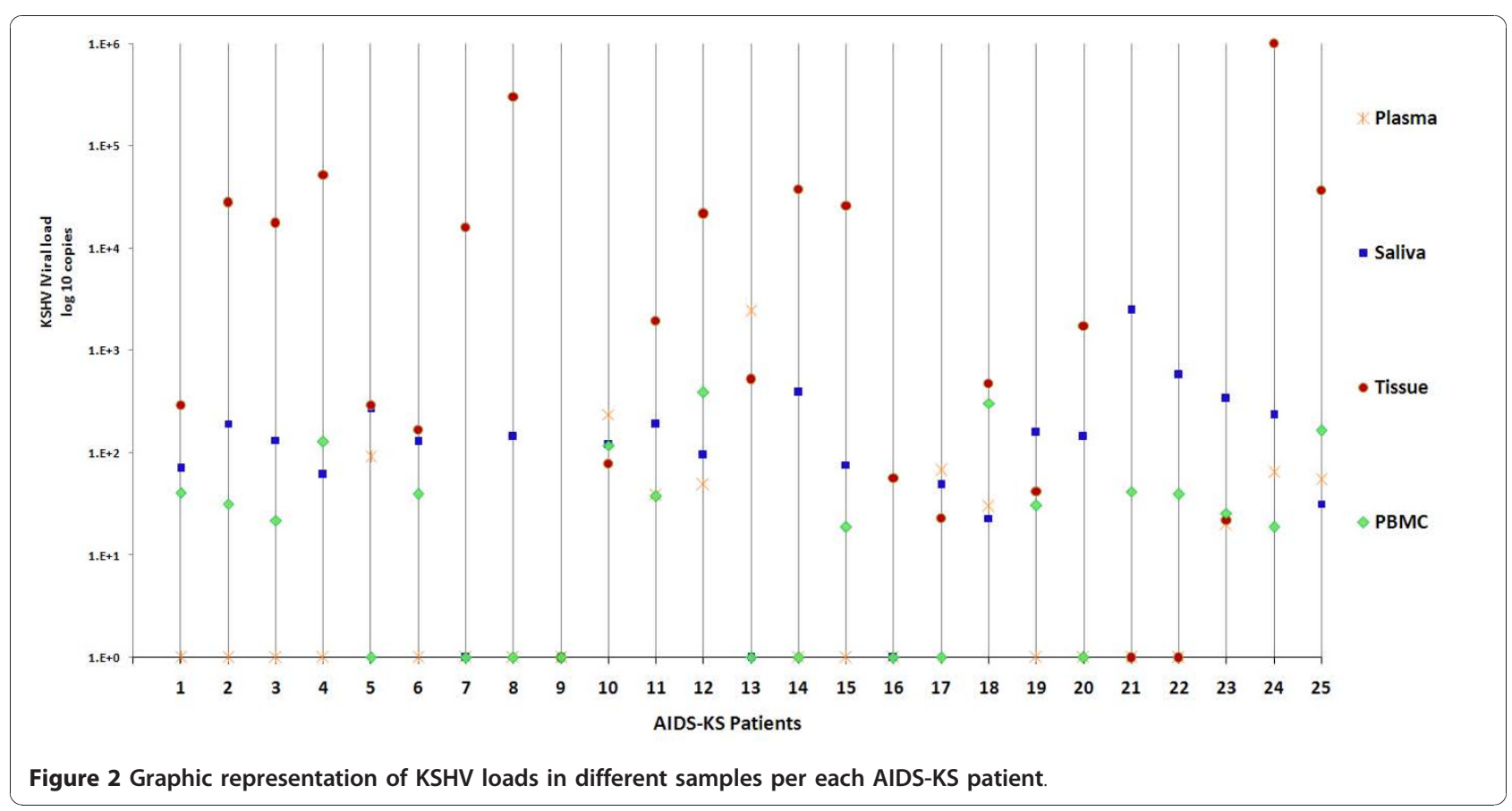


sexual intercourse, as the presence of HHV-8 in semen, anal secretions or vaginal fluid has not been consistently demonstrated [27-30].

\section{Acknowledgements}

This work have been supported by the Joachim Kuhlmann AIDS Foundation, Essen, Germany.

\section{Author details}

'Institute of Tropical Medicine "Pedro Kouri", Havana City, Cuba. 'LatinAmerican School of medicine, Havana City, Cuba. ${ }^{3}$ Skin Center, Düsseldorf, Germany.

\section{Authors' contributions}

All authors read and approved the final manuscript. VK and PAM participated in the conception and design, acquisition of data, analysis and interpretation of data, drafted the manuscript. OB, MER, MdCD and NA made the clinical diagnosis and patients follow up, sampling, clinical analysis and interpretation of data. LC and AG participated in the design of the study and performed the statistical analysis. CC, YA, LP and AA carried out the molecular genetic studies. Finally, UH participated in the design of the study and drafted the manuscript.

\section{Competing interests}

The authors declare that they have no competing interests.

Received: 7 July 2010 Accepted: 7 December 2010

Published: 7 December 2010

\section{References}

1. Volkenandt M, Dicker A, Fanin R, Banerjee D, Albino S, Bertino JR: Polymerase Chain Reaction Analysis of DNA from Paraffin-Embedded Tissue. In Methods in Molecular Biology PCR protocols: Current Methods and Applications Edited by: Inc HP EUA 1993, 81-87.

2. Yin JL, Shackel NA, Zekry A, McGuinness PH, Richards C, Putten KV, McCaughan GW, Eris JM, Bishop GA: Real-time reverse transcriptasepolymerase chain reaction (RT-PCR) for measurement of cytokine and growth factor mRNA expression with fluorogenic probes or SYBR Green I. Immunol Cell Biol 2001, 79:213-221.

3. Schmitz M, Scheungraber C, Herrmann J, Teller K, Gajda M, Runnebaum IB, Durst M: Quantitative multiplex PCR assay for the detection of the seven clinically most relevant high-risk HPV types. J Clin Virol 2009, 44:302-307.

4. Watzinger F, Suda M, Preuner S, Baumgartinger R, Ebner K, Baskova L, Niesters HG, Lawitschka A, Lion T: Real-time quantitative PCR assays for detection and monitoring of pathogenic human viruses in immunosuppressed pediatric patients. J Clin Microbiol 2004, 42:5189-5198.

5. Calonje E, Wilson Jones E: Tumors and Tumor-like conditions of blood vessels and lymphatics. In Lever's Histopathology of the skin. 8 edition. Edited by: Elder D, Elenitsas R, Jaworsky C, Jhonson BJ. USA: Lippincott Williams 1999:623-651.

6. Mendez JC, Procop GW, Espy MJ, Paya CV, Smith TF: Detection and semiquantitative analysis of human herpesvirus 8 DNA in specimens from patients with Kaposi's sarcoma. J Clin Microbiol 1998, 36:2220-2222.

7. Kennedy MM, Cooper K, Howells DD, Picton S, Biddolph S, Lucas SB, McGee JO, O'Leary JJ: Identification of HHV8 in early Kaposi's sarcoma: implications for Kaposi's sarcoma pathogenesis. Mol Pathol 1998, 51:14-20.

8. Coombs NJ, Gough AC, Primrose JN: Optimisation of DNA and RNA extraction from archival formalin-fixed tissue. Nucleic Acids Res 1999, 27:e12

9. Pyakurel P, Pak F, Mwakigonja AR, Kaaya E, Biberfeld P: KSHV/HHV-8 and HIV infection in Kaposi's sarcoma development. Infect Agent Cancer 2007, 2:4.

10. Zeng $Y$, Zhang X, Huang Z, Cheng L, Yao S, Qin D, Chen X, Tang Q, Lv Z, Zhang L, Lu C: Intracellular Tat of human immunodeficiency virus type 1 activates lytic cycle replication of Kaposi's sarcoma-associated herpesvirus: role of JAK/STAT signaling. J Virol 2007, 81:2401-2417.

11. de Souza VA, Sumita LM, Nascimento MC, Oliveira J, Mascheretti M, Quiroga M, Freire WS, Tateno A, Boulos M, Mayaud P, Pannuti CS: Human herpesvirus-8 infection and oral shedding in amerindian and nonamerindian populations in the brazilian Amazon region. J Infect Dis 2007, 196:844-852.

12. Al-Otaibi LM, Ngui SL, Scully CM, Porter SR, Teo CG: Salivary human herpesvirus 8 shedding in renal allograft recipients with Kaposi's sarcoma. J Med Virol 2007, 79:1357-1365.

13. Leao JC, Caterino-De-Araujo A, Porter SR, Scully C: Human herpesvirus 8 (HHV-8) and the etiopathogenesis of Kaposi's sarcoma. Rev Hosp Clin Fac Med Sao Paulo 2002, 57:175-186.

14. Kouri V, Eng SM, Rodriguez ME, Resik S, Orraca O, Moore PS, Chang Y: Seroprevalence of Kaposi's sarcoma-associated herpesvirus in various populations in Cuba. Rev Panam Salud Publica 2004, 15:320-325.

15. Gasperini P, Barbierato M, Martinelli C, Rigotti P, Marchini F, Masserizzi $G$ Leoncini F, Chieco-Bianchi L, Schulz TF, Calabro ML: Use of a BJAB-derived cell line for isolation of human herpesvirus 8. J Clin Microbiol 2005, 43:2866-2875.

16. Boivin G, Cote S, Cloutier N, Abed Y, Maguigad M, Routy JP: Quantification of human herpesvirus 8 by real-time PCR in blood fractions of AIDS patients with Kaposi's sarcoma and multicentric Castleman's disease. J Med Virol 2002, 68:399-403.

17. Martro E, Cannon MJ, Dollard SC, Spira TJ, Laney AS, Ou CY, Pellett PE: Evidence for both lytic replication and tightly regulated human herpesvirus 8 latency in circulating mononuclear cells, with virus loads frequently below common thresholds of detection. J Virol 2004, 78:11707-11714.

18. Harrington WJ Jr, Bagasra O, Sosa CE, Bobroski LE, Baum M, Wen XL, Cabral L, Byrne GE, Pomerantz RJ, Wood C: Human herpesvirus type 8 DNA sequences in cell-free plasma and mononuclear cells of Kaposi's sarcoma patients. J Infect Dis 1996, 174:1101-1105.

19. Kuo CP, Wu CL, Ho HT, Chen CG, Liu SI, Lu YT: Detection of cytomegalovirus reactivation in cancer patients receiving chemotherapy. Clin Microbiol Infect 2008, 14:221-227.

20. Garrigue I, Doussau A, Asselineau J, Bricout H, Couzi L, Rio C, Merville P, Fleury H, Lafon ME, Thiebaut R: Prediction of cytomegalovirus (CMV) plasma load from evaluation of CMV whole-blood load in samples from renal transplant recipients. J Clin Microbiol 2008, 46:493-498.

21. Brantsaeter AB, Holberg-Petersen M, Jeansson S, Goplen AK, Bruun JN: CMV quantitative PCR in the diagnosis of CMV disease in patients with HIVinfection-a retrospective autopsy based study. BMC Infect Dis 2007, 7:127

22. Polstra AM, Cornelissen M, Goudsmit J, van der Kuyl AC: Retrospective, longitudinal analysis of serum human herpesvirus-8 viral DNA load in AIDS-related Kaposi's sarcoma patients before and after diagnosis. $J$ Med Virol 2004, 74:390-396.

23. Moore PS, Chang Y: Kaposi's Sarcoma-Associated Herpesvirus. In Fields Virology. Volume 2. 4 edition. Edited by: Knipe DM, Howley PM, Griffin DE, Lamb RAM MA, Roizman B, Straus SE. USA: LIPPINCOTT WILLIAMS 2001:2803-2833.

24. Nawar E, Mbulaiteye SM, Gallant JE, Wohl DA, Ardini M, Hendershot T, Goedert JJ, Rabkin CS: Risk factors for Kaposi's sarcoma among HHV-8 seropositive homosexual men with AIDS. Int J Cancer 2005, 115:296-300

25. Alkharsah KR, Dedicoat M, Blasczyk R, Newton R, Schulz TF: Influence of HLA Alleles on Shedding of Kaposi Sarcoma-Associated Herpesvirus in Saliva in an African Population. J Infect Dis 2007, 195:809-816.

26. Casper C, Carrell D, Miller KG, Judson FD, Meier AS, Pauk JS, Morrow RA, Corey L, Wald A, Celum C: HIV serodiscordant sex partners and the prevalence of human herpesvirus 8 infection among HIV negative men who have sex with men: baseline data from the EXPLORE Study. Sex Transm Infect 2006, 82:229-235.

27. Corbellino M, Pizzuto M, Bestetti G, Corsico L, Piazza M, Pigozzi B, Galli M, Baldini L, Neri A, Parravicini C: Absence of Kaposi's sarcoma-associated herpesvirus DNA sequences in multiple myeloma. Blood 1999, 93:1110-1111.

28. Viviano E, Gallo E, Bongiorno MR, Romano N: [The genomic sequences of the human herpesvirus 8 in biological samples from HIV-positive andnegative subjects in Sicily]. Ann Ig 1999, 11:507-509.

29. Engels EA, Atkinson JO, Graubard BI, McQuillan GM, Gamache C, Mbisa G, Cohn S, Whitby D, Goedert JJ: Risk Factors for Human Herpesvirus 8 Infection among Adults in the United States and Evidence for Sexual Transmission. J Infect Dis 2007, 196:199-207. 
30. Taylor MM, Chohan B, Lavreys L, Hassan W, Huang ML, Corey L, Ashley Morrow R, Richardson BA, Mandaliya K, Ndinya-Achola J, et al: Shedding of human herpesvirus 8 in oral and genital secretions from HIV-1seropositive and-seronegative Kenyan women. J Infect Dis 2004, 190:484-488

doi:10.1186/2042-4280-1-3

Cite this article as: Kourí et al: Simultaneous quantification of human herpesvirus 8 DNA by real time PCR in different tissues of HIV infected cuban patients with Kaposi's sarcoma. Herpesviridae 2010 1:3.

Submit your next manuscript to BioMed Central and take full advantage of:

- Convenient online submission

- Thorough peer review

- No space constraints or color figure charges

- Immediate publication on acceptance

- Inclusion in PubMed, CAS, Scopus and Google Scholar

- Research which is freely available for redistribution

Submit your manuscript at www.biomedcentral.com/submit
() Biomed Central 